Natalita VolchenKo

$\mathrm{PhD}$, associate professor of International RelationsChair

Sumy National Agrarian University

natavol4enko@gmail.com

ORCID: 0000-0002-5748-972X

NataliIa KLIETSOVA

$\mathrm{PhD}$, associate professor of International Relations Chair

Sumy National Agrarian University

klietsovanataliia@gmail.com

ORCID: 0000-0003-4910-8912

\title{
Theoretical Principles of Employees' Rights Protection in the Context OF RESPONSIBILITY FOR MOBBING
}

\begin{abstract}
Purpose of the work is to investigate theoretical principles of employees' rights protection in the context of responsibility for mobbing. The theoretical and methodological basics of the research are general scientific and special methods of certain jurisprudence phenomena and processes' cognition. The dialectical method was used in the synthesis of theoretical and methodological foundations of employment policy abroad and in Ukraine, as well as formulating conclusions. Thus, we used a common dialectic method which allowed us to reveal the content of employer, employee and mobbing in the context of the domestic and foreign scholars' experience. We also have used abstract and logical investigation methods of law process in the field of employee's rights protection. Statistical methods were used for analyzing trends of employee's rights in different countries. The authors investigated: the main stages of the employment in Ukraine; focused attention on three events that occur during the legal employment of a hired worker; the definition of the mobbing, its concept, the experience of counteracting and establishing responsibility for this offense in the EU. The paper identified the main principles of the mobbing counteracting system's development in Ukraine. In further investigations it is necessary to make a distinction between actions that
\end{abstract}


take place exclusively at the workplace while performing employee's duties and extending to more private aspects of a person's life (correspondence, messengers, telephone calls at a time that is not formally a working).

KEYWORDS: mobbing, hired employee, hired worker, administrative offense, labor relations, responsibility, human rights

\section{INTRODUCTION}

According to the Article 1 of the Law of Ukraine "On the Procedure for the Resolution of Collective Labor Disputes (Conflicts)" (Law of Ukraine On the Procedure for the Resolution of Collective Labor Disputes (Conflicts), 1998), a hired worker or employee is an individual who works under an employment contract at an enterprise, institution and organization, in their associations or from individuals who use hired labor. When hiring an employee, you must always comply with the requirements of labor legislation. So, according to paragraph 14.1.222 of the Tax Code of Ukraine (Tax Code of Ukraine, ${ }^{2010)}$ and Part 1 of the Art. 1 of the Law of Ukraine "On Employers' Organizations" (Law of Ukraine On the organization of employers, their association, rights and guarantees of their activities, ${ }^{2012)}$ if an entrepreneur uses the labor of individuals, he or she is considered to be an employer. The relationship between the employee and the employer is based on an employment contract.

Purpose of the work is to investigate theoretical principles of employees' rights protection in the context of responsibility for mobbing.

The theoretical and methodological basics of the research are general scientific and special methods of certain jurisprudence phenomena and processes' cognition. The dialectical method was used in the synthesis of theoretical and methodological foundations of employment policy abroad and in Ukraine, as well as formulating conclusions. Thus, we used a common dialectic method which allowed us to reveal the content of employer, employee and mobbing in the context of the domestic and foreign scholars' experience. We also have used abstract and logical investigation methods of law process in the field of employee's rights protection. Statistical methods were used for analyzing trends of employee's rights in different countries. 
Consider a situation where a hired worker successfully interviewed and was notified about employment in the company. At the same time, we emphasize that since $1^{\text {st }}$ January 2015, the article 24 of the Labor Code (Labour code of Ukraine, 1971) amended that an employee cannot be admitted to work without the conclusion of an employment contract drawn up by an order of the employer and the reports of the relevant authorities on the acceptance of the employee for work. According to the current legislation, such notice of the acceptance of an employee to work is filed by the owner of the enterprise, institution, organization or authorized body (person) or individual to the territorial bodies of the State Fiscal Service at the place where they are registered as a payer of a single contribution before the employee starts working. We would like to emphasize that such a notice must be submitted when each new employee is hired. Thus, according to the labor legislation of Ukraine, an employee can be admitted to work if there were three main events, depicted in Fig. 1.

In our opinion, it is worth paying attention to the second and third events on the fig. 1. Thus, in accordance with paragraph 6 part 1 of the Art. 24 Labor Code, an employment contract with an individual is compulsory in a writing form. Moreover, the established form approved by the Order of the Ministry of Labor and Social Policy of Ukraine No. 260 (Approval of Forms of an Employment Contract between an Employee and an Individual Employed by the Employer and the Procedure for Registration of an Employment Contract between an Employee and an Individual Employing the Employed Work, 2001) can be used. Also, certain clauses can be added to the employment contract if they do not worsen the working conditions of the hired worker (Article 9 of the Labor Code).

To conclude an agreement, an employee must provide: an application for employment; passport or other identity document; record book (if any). If the work requires an appropriate education or qualification or a confirmation that the employee does not contraindicate the performance of this type of work due to the health condition of the employee, according to Part 2 of Art. 24 of the Labor Code should provide: a document on education; health document; other documents (for example, a military document) in cases provided for by law. 
Fig. 1

The Main three Events Under which there is no Hidden Labor Relations

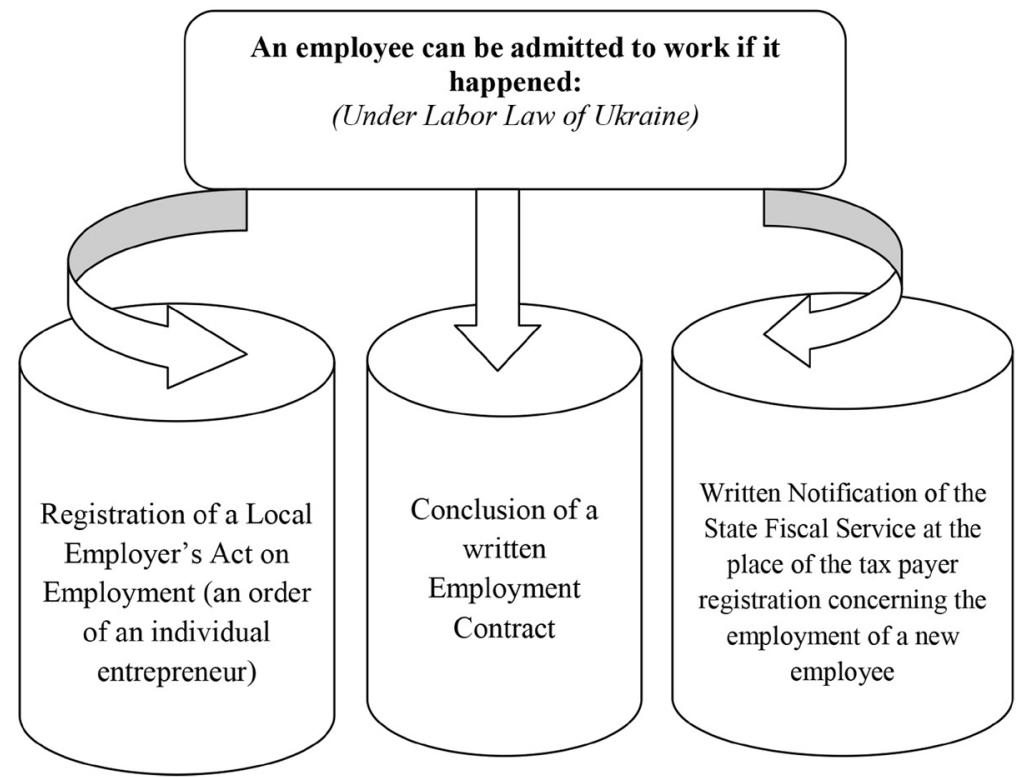

Source: prepared by the authors in accordance with the Labor Legislation of Ukraine (Klietsova, 2018, 255)

The next event is a written statement from the State Fiscal Service at the place where the taxpayer registers the recruitment of a new employee. The notice is submitted before the employee starts work according to the established form of legislation in one of the following ways: 1) by means of electronic communication using the electronic digital signature of the responsible persons; 2) in paper form with a copy in electronic form (on a disk or a flash disk); 3) only in paper form, if the number of employees in the enterprise is not more than five persons. The peculiarity of this stage is that the date of the order (the order) on recruitment and the actual date of commencement of work will be different. In addition, if a civil law contract has been concluded with the employee, then it is not necessary to submit a notice to the State Fiscal Service. Consequently, since the signing of an employment contract, there are automatically certain obligations and rights of both the employee and the employer. 
Today in Ukraine, the issue of the rights of an employee to work, which according to international agreements is recognized as one of the basic socioeconomic rights of people, becomes a matter of special urgency. In particular, the European Social Charter (European Social Charter, 1996) states that the state undertakes to recognize one of its main objectives and one of its most important responsibilities to achieve and maintain the highest possible and stable level of employment, with the aim of achieving full employment, and to effectively protect the right of an employee to earn a living in a profession that a person freely chooses. In turn, Ukraine has undertaken to respect, protect and implement this right. At the same time, there are significant problems with the fulfillment of our obligations.

In particular, despite the presence of a fairly large array of legislation that regulates this area, many of its provisions remain declarative. For example, the official level of unemployment has long failed to reflect its real level and shows that the state has a distorted picture of unemployment in Ukraine and, therefore, is not able to ensure the implementation of an effective employment policy.

According to the European Social Charter, "All workers have the right to a fair remuneration that will provide a sufficient standard of living for themselves and their families" (European Social Charter, 1996). At the same time, in Ukraine, the most widespread phenomenon is the poverty of the working population, more than half of the population receives wages much lower than their average level. A large percentage of the population of Ukraine works under civil contracts, receiving a wage lower than the minimum one.

Creating safety guarantees is an important condition for ensuring the right to work. Even official statistics on occupational accidents and occupational diseases in Ukraine show that the number of such cases exceeds the number of the same ones in the European countries. However, in 2018, compared to previous years, the percentage of industrial accidents in Ukraine decreased by $10 \%$. Thus, according to official data, for example, in 2016, there were 8409 industrial accidents in Ukraine, in which 8670 people were injured, including 1,200 deaths. By comparison, in the United Kingdom of Great Britain and Northern Ireland in 2016 only 113 people were killed, 529 deaths were reported in France in 2015, 557 deaths in Germany in 2017 (Report 
of human rights organizations. Ukrainian Helsinki Human Rights Union, 2018). Thus, the level of deaths from industrial accidents in Ukraine is much higher than in leading European countries, even without taking into account the difference in the number of able-bodied population.

Speaking about the real employment of the country, most researchers begin their investigation with macro issues, including processes that impede the stable country's development. And only some scientists immediately start their research with the employment policy's obstacles at the micro level. We mean the enterprises' motivation policy or the so-called "energetic forces" (Broeck, 2016, 1195-1229), (Illiashenko, 2016, 49-53) that initiate the employees' behavior at their position.

The question arises, what is the responsibility for violating labor relations, for improper working conditions, for violation of the rights to work of the Ukrainian citizens etc.? For example, for violations of labor legislation, legal entities and individuals - entrepreneurs who use hired labor have a certain responsibility. Today, the law provides for five types of liability: disciplinary, administrative, material, financial and criminal. In this case, these types of liability will be applied independently of each other. It should be noted that it is precisely on the basis of the results of the State Labor Inspection that officials can be brought to administrative and criminal responsibility, and in particular the company - to financial responsibility.

What are the reasons that hinder the human right to work? One of them is conflicts in labor relations, which are related to the violation of the hired employee' rights. They are particularly a difficult area of study in view of the cross-cutting effects of psychological, sociological, legal, economic and managerial factors. Quite often, human rights of hired employee are violated purposefully in order not to allow him/her to reach a certain position at the enterprise or organization. It will be critical situation if pressure on a person is carried out in order to bring him to a state in which he cannot perform his direct duties. Final result can be even dismissal. The most socially dangerous consequence may be even the suicide of a person who has been subjected to such harassment. It was proved that underemployment reduced the level of employees' productivity up to $30 \%$ (Nunley, 2016, 37-46). The situation described above is called mobbing. 
It is well known that for the first time, the term of mobbing was used by Heinz Leymann, a Swedish psychologist who initially investigated hostility in the relationship between schoolchildren, and then drew attention to psychological pressure in the workplace. In one of his writings, he noted that employees often find a person who becomes the object and purpose of their psychological pressure. The term "mobbing" was applied to this phenomenon. It occurs when the victim is subjected to systematic shame, psychological pressure, including through injustice. In fact, we can say that human rights in the workplace are violated.

Professor Leymann in his works offered a range of measures that could resist the proliferation of this problem at the enterprises. In his algorithm it was stated that the parties agreed on reconciliation; application of intermediaries that would represent the interests of the parties; depersonalization of the conflict by moving from personal interests to the real causes of the conflict; the negotiation process to mitigate the expectations of the parties; conclusion of the agreement; providing psychological assistance to the victim (Leymann, 1990, 119-126). From the point of interpersonal relations in the collective, this problem may be solved, but it is not clear how the mechanism of responsibility for such actions will work, and whether there will be a repetition of similar actions in relation to other representatives of the labor collective.

The notion of mobbing proposed by D. Zapf and S. Einarsen is widely used. Authors interpret mobbing as persecution, insults, social rejection, which have a negative impact on the working tasks of person (Zapf, Einarsen, 2005, 237 270). If terminology is associated with persecution, then it is obvious that there is a need for repetition and regularity of the offender's actions to qualify them as mobbing. Social rejection suggests that mobbing usually occurs in relation to a person who is weaker than the attacker. Consequently, in situations where the parties have the same forces, capabilities, potential, etc., the situation will qualify as a conflict. In addition, one-time incidents that do not repeat and do not have a system cannot be recognized by mobbing.

In order to prevent negative consequences, or at least to make their consequences less dangerous, in our opinion, it is necessary to resort to penalisation practice. To do this, it is necessary, first of all, to resolve the 
issues of counteracting mobbing and responsibility for its committing in legal acts and counteraction to this phenomenon. Especially since the solution of this problem will directly affect the right to fair and safe working conditions and prevent the humiliation of the honor and dignity of every employee of the enterprise.

Persons, which prefer mobbing's practice, can change objects of influence periodically, but they always have an urgent need to have a victim. There is also a pathological reluctance to admit its behavior as destructive and to accuse the victim of everything (Алексєєнко, 2018, 19-25). The absence of a system for countering and mobbing's punishment stimulates aggressive behavior of individuals that are already prone to such actions.

The beginning of this issue's regulation and counteracting this phenomenon is initiated by introduction of a draft law "On Amendments to Certain Legislative Acts of Ukraine on Combating Mobbing" (No. 10118 dated $1^{\text {st }}$ March 2019). According to authors' point of view, mobbing is interpreted as an act of participants in labor relations consisting in psychological, physical, economic violence, including the usage of electronic means of communications; which is committed against to the employee of an enterprise, institution, organization irrespective of the form of ownership, type of activity and branch affiliation, as well as persons who work under an employment contract with individuals or a person with respect to other participants in labor relations with the aim of humiliating their human dignity by certain signs, the creation of a tense, hostile, insulting atmosphere in relation to them, and forcing a participants in labor relations to change their place of work (Alexander Spivakovsky about draft law on combating mobbing, 2019).

There is a need for changes to the Code of Ukraine on Administrative Offenses. The article 173 of the draft law proposes to supplement the responsibility for the mobbing in the above interpretation of this notion. The punishment for mobbing is provided by imposing a fine of 50 to 100 taxfree minimum of citizens' incomes, or public works for a period of 20 to 40 hours. A repeated case of mobbing (after imposing a fine) or committed by a group of individuals, increases the penalties' amount that can be doubled and extends the time limit for the usage of public works from 40 to 60 hours. 
A similar to repeated case's punishment it is offered for the assumption of mobbing, which caused injury to the mental or physical health of a participant in labor relations, or mobbing by the owner or the body authorized by him. It is logical to punish failure to report on known mobbing's facts by owners or their authorized bodies. The authors of the draft propose cases of mobbing to be considered by judges of district, district in cities, city or intercity courts. Officials of the National Police, as well as in other cases of administrative offenses, will be able to draw up protocols on the administrative offense according to mobbing.

The above mentioned changes (if adopted) should be correspondent with changes in labor legislation and regulations on human rights protection. Works of national specialists in labor law confirm this fact. Thus, O. Kravchenko proposes to bring the concept of mobbing into the draft of Labor Code of Ukraine, to establish liability for the committing of such actions; to prohibit mobbing in internal regulatory acts of the enterprise; to impose sanctions for demonstration of mobbing (Kravchenko, 2018, 90-91).

On the way to European integration within the framework of harmonization of Ukrainian legislation, it is expedient to turn to the European experience of countering mobbing and responsibility for its manifestation in relation to hired employees. Unprecedented respect for human rights in the European Union excludes the possibility that harassment of hired employees in any form will remain unattended.

Employers have a significant share of responsibility for respect of hired employees in the EU Directives. In particular, the Directive 89/391 condemns moral persecution and psychological violence against employees, which entails risks to the health and safety of employees (Council Directive 89/391/ EEC, 1989). Essentially, the possibility of such situations should be monitored by employers. They are accordingly committed to eliminate such threats. The European Parliament also endorsed Resolution A5-0283/2001) (Mobbing. European Foundation for the Improvement of Living and Working Conditions). It calls upon EU Member States to review and complete the development of their legislative framework for measures to combat mobbing.

The Directive 2000/78/EU (Council Directive 2000/78/EU, 2000), which establishes the general framework for equal treatment in employment and 
occupation, defines the right of all people to equality before the law and protection against discrimination recognized by the Universal Declaration of Human Rights, the United Nations Convention on the Elimination of All Forms of Discrimination against Women, the International Convention on the Elimination of All Forms of Racial Discrimination and the United Nations International Covenants on Civil and Political Rights and on Economic, Social and Cultural Rights and the European Convention on the Protection of Human Rights and Fundamental Freedoms, signed by all member states.

Today limited numbers of EU's countries (like Sweden) have adopted a special law on mobbing in the workplace. Other EU member states are working on legislative proposals (for example, Italy).

The Work Environment Act has been adopted in Sweden. It defines the need to ensure a sufficient level of conditions for safe work not only physically, but also psychologically. The legal act regulating the issue of a bullying directly is the Victimization at Workplace (1993), which provides definitions and determines the direct actions that characterize this phenomenon. In particular, it is intimidation, psychological violence, social exclusion, harassment, etc. (Yamada, 2004, 475).

In some countries, in particular in Italy, mobbing's regulation is based on judicial practice. A. Sorokina (Sorokina, 2018, 139-146) in her studies refers to the case of 1999 , considered by the court of the Turin city. The hired employee claimed compensation for the damage resulting from depression. It was caused by hard conditions of work, continuous and purposeful persecution and humiliation by the head of the department. The Italian practice characterizes mobbing as a manifestation of psychological pressure, negative attitude and open aggression towards a hired employee. The protection of the rights of a hired employee from mobbing, thus, is based on a broad judicial interpretation of the need for personal protection.

The current work on the system's formation for countering mobbing in Ukraine should relate primarily to the establishment of a clear categorical apparatus. In addition to a scientifically based definition, it is necessary to clearly establish the criteria that will qualify actions as mobbing. Separately, in our opinion, should be determined by mobbing from the owner (leader) of the enterprise, the direct manager, or employees. The distinction between 
these concepts will be based on different causes of harassment. Individuals practicing mobbing may be guided by different circumstances, which will lead to various consequences and "aggressiveness" of the perpetrator's actions. In further investigations it is necessary to make a distinction between actions that take place exclusively at the workplace while performing employee's duties and extending to more private aspects of a person's life (correspondence, messengers, telephone calls at a time that is not formally a working).

\section{References}

Aleksieienko T. (2018) Bulinh i mobinh: prychyny rozvytku i shliakhy profilaktyky (Bullying and mobing: causes of development and prevention). Osobystist u prostori vykhovnykh innovatsii: materialy Vseukrainskoi naukovo-praktychnoi konferentsii (Instytut problem vykhovannia NAPN Ukrainy 2018), 19-25. (In Ukrainian).

Broeck A. A., Ferris D. Lance, Chang Chu-Hsiang, Rosen Christopher C. (2016) Review of Self-Determination Theory's Basic Psychological Needs at Work. Journal of Management. 42. № 5, 1195-1229. ISSN 0149-2063.

Council Directive 89/391/EEC of 12 June 1989 on the introduction of measures to encourage improvements in the safety and health of workers at work $<$ https://eur-lex.europa.eu/LexUriServ/LexUriServ.do?uri=CELEX:31989L0391:EN:HTML> access date: $1^{\text {st }}$ March 2019.

Dyrektyva Rady 2000/78/IeC vid 27 lystopada 2000 roku, shcho vstanovliuie zahalni ramky rivnosti opravnoho povodzhennia u sferi zainiatosti i profesiinoi diialnosti (ofitsiinyi pereklad ministerstva yustytsii Ukrainy) Council Directive 2000/78/ EU of November, the $27^{\text {th }} 2000$ established a framework for equal treatment in employment and occupation (Official translation from the Ministry of Justice of Ukraine) <http://ecmi-epp.org/wp-content/uploads/2015/03/Council-2000_78_ EC_UK.pdf $>$ access date: $15^{\text {st }}$ October 2019. (In Ukrainian).

Human rights in Ukraine - 2017. (Report of human rights organizations. Ukrainian Helsinki Human Rights Union. K., 2018. <https://zakon.rada.gov.ua/laws/ show/994_062> access date: $16^{\text {th }}$ February 2019.

Illiashenko S., Rot-Sierov Yev. (2016) Knowledge as a factor of competitive advantages: prospects for Ukraine. Economic Annals-XXI. Vol. 156, Issue 1-2, 49-53.

Klietsova N. Improvement of the Ukrainian Labor Legislation Concerning the Hired Workers' Employment Protection in the Context of European Integration. Nauchni trudove. 2018. \#2. P. 251-264 (University of National and World Economy, Sofia, Bulgaria) 
Kodeks zakoniv pro pratsiu Ukrainy (Labour code of Ukraine) / Zatverdzhenyi Zakonom № 322-VIII (322a-08) vid 10.12.1971. Vidomosti Verkhovnoi Rady. 1971. № 50. (Z podalshymy zminamy, vnesenymy zghidno z Ukazamy Prezydii VR Ukrainskoi RSR, Zakonamy Ukrainskoi RSR i Zakonamy Ukrainy). < http://zakon4.rada.gov.ua/laws/show/322-08> access date: $1^{\text {st }}$

February 2019 (In Ukrainian)

Kravchenko, O. (2018) Mobinh u trudovomu pravi. (Mobbing in labor law) Visnyk APSVT, №3, 90-91. (In Ukrainian). ISSN 2519-4704.

Leymann, H. (1990). Mobbing and psychological terror at workplaces. Violence and victims, 5(2), 119-126. ISSN 0886-6708.

Mobbing. European Foundation for the Improvement of Living and Working Conditions <https://www.eurofound.europa.eu/observatories/eurwork/industrial-relations-dictionary/mobbing > access date: $1^{\text {st }}$ March 2019.

Nunley J. M., Pugh A., Romero N, Seals R. Alan (2016) College Major, Internship Experience, and Employment Opportunities: Estimates from a Resume Audit. Labour Economics. Vol. 38, № 1. 37-46. ISSN 0927-5371.

Oleksandr Spivakovskyi pro zakonoproekt shchodo protydii mobinhu (Alexander Spivakovsky about draft law on combating mobbing) (15 $5^{\text {th }}$ Oktober 2019 , 11:33) <http://khersonci.com.ua/public/35579-oleksandr-spivakovskij-prozakonoproekt-shchodo-protidiji-mobingu.html> access date: $25^{\text {th }}$ October 2019. (In Ukrainian).

Podatkovyi kodeks Ukrainy (Tax Code of Ukraine): Zatverdzhenyi Zakonom № 2755-VI vid 02.12.2010. Vidomosti Verkhovnoi Rady Ukrainy. - 2011 (zi zminamy ta dopovnenniamy).http://zakon4.rada.gov.ua/laws/show/2755-17 access date: $14^{\text {th }}$ December 2018 (In Ukrainian).

Pro zatverdzhennia Formy trudovoho dohovoru mizh pratsivnykom i fizychnoiu osoboiu, yaka vykorystovuie naimanu pratsiu, ta Poriadku reiestratsii trudovoho dohovoru mizh pratsivnykom i fizychnoiu osoboiu, yaka vykorystovuie naimanu pratsiu. (Approval of Forms of an Employment Contract between an Employee and an Individual Employed by the Employer and the Procedure for Registration of an Employment Contract between an Employee and an Individual Employing the Employed Work.) Nakaz Ministerstva pratsi ta sotsialnoi polityky Ukrainy № 260 vid $08.06 .2001<$ https://zakon.rada.gov.ua/laws/show/z0554-01> access date: 5th February 2019. (In Ukrainian).

Sorokina, A. A. (2018). Mobinh ta bulinh v trudovykh vidnosynakh (Mobbing and bullying in labor relations). Young, 63(11), 139-146. ISSN 1741-3222. 
Yamada, D. C. (2004). Crafting a legislative response to workplace bullying. Emp. Rts. \& Emp. Pol'y J., 8, 475.

Yevropeiska sotsialna khartiia. (European Social Charter) № 994_062 vid 03.05.1996. Rada Yevropy. <https://zakon.rada.gov.ua/laws/show/994_062> access date: $16^{\text {th }}$ February 2019 (In Ukrainian).

Zakon Ukrainy «Pro orhanizatsii robotodavtsiv, yikh obiednannia, prava i harantii yikh diialnosti» (Law of Ukraine On the organization of employers, their association, rights and guarantees of their activities) № 5026-VI vid 22.06.2012. Vidomosti Verkhovnoi Rady Ukrainy. <https://zakon.rada.gov.ua/laws/show/5026-17> access date: $9^{\text {th }}$ August 2019 (In Ukrainian).

Zakon Ukrainy «Pro poriadok vyrishennia kolektyvnykh trudovykh sporiv (konfliktiv)» (Law of Ukraine On the Procedure for the Resolution of Collective Labor Disputes (Conflicts)) №137/98-VR vid 03.03.1998. Vidomosti Verkhovnoi Rady Ukrainy. <https://zakon.rada.gov.ua/laws/show/137/98-\%D0\%B2\%D1\%80> access date: $4^{\text {th }}$ February 2019 (In Ukrainian).

Zapf, D. \& Einarsen, S. (2005). Mobbing at Work: Escalated Conflicts in Organizations. In: S. Fox \& P. E. Spector (Eds.), Counterproductive work behavior: Investigations of actors and targets, 237-270. ISBN 9781591471653. 
